\section{A Chilling Model to Estimate Rest Completion of Erect Blackberries}

\author{
Michele R. Warmund ${ }^{1}$ and Joan Krumme ${ }^{2}$ \\ Department of Horticulture, University of Missouri, Columbia, MO 65211
}

Additional index words. Rubus, chill units, cold requirement, dormancy

\begin{abstract}
The time of rest completion of 'Apache', 'Arapaho', 'Chickasaw', 'Darrow', 'Kiowa', 'Navaho', and 'Shawnee' blackberry (Rubus subgenus Rubus Watson) buds was compared and various models for estimating chilling were evaluated. 'Kiowa' and 'Arapaho' buds had the shortest rest periods, while those for 'Shawnee', 'Navaho', and 'Chickasaw' buds were intermediate. 'Apache' and 'Darrow' buds had the longest rest periods. The model that accounted for the variation in percent budbreak among cultivars and temperatures during two dormant periods had the following two components: 1) a chilling inception temperature of $-2.2^{\circ} \mathrm{C}$ and 2 ) weighted chilling hours that accumulated after the chilling inception temperature. The chilling hours in this model were weighted as follows: 0 to $9.1^{\circ} \mathrm{C}=1 ; 9.2$ to12.4 ${ }^{\circ} \mathrm{C}$ $=0.5 ; 12.5$ to $15.9^{\circ} \mathrm{C}=0 ; 16$ to $18{ }^{\circ} \mathrm{C}=-0.5 ;>18^{\circ} \mathrm{C}=-1$. This study also elucidated that a blackberry model with a chilling inception temperature of $-2.2^{\circ} \mathrm{C}$ estimated chilling more accurately than one with chilling inception just after the maximum negative accumulation of chill units as used in the Utah chilling model. Also, temperatures between 0 and $2.4{ }^{\circ} \mathrm{C}$ must be weighted more heavily in a blackberry model than in the Utah peach model to accurately estimate chilling and rest completion.
\end{abstract}

Many temperate zone fruit plants require a period of low temperatures during dormancy to grow vegetatively and produce flowers in the spring. The number of hours necessary to fulfill the chilling requirement varies among fruit crops (Westwood, 1993) and cultivars (Dale et al., 2003). Several models have been used to estimate the chilling requirements and to predict the time of rest completion. In 1932, Hutchins proposed a model for peach that accumulated chilling hours at temperatures $\leq 7$ ${ }^{\circ} \mathrm{C}$ (Weinberger, 1950). Chandler et al. (1937) studied chilling of deciduous fruit trees, small fruit crops, and ornamentals, and Lamb (1948) examined effective chilling temperatures in 'Latham' raspberry. Both studies indicated that temperatures from 0 to $7^{\circ} \mathrm{C}$ were most effective in satisfying the cold requirement. For peach, temperatures as low as $1.5^{\circ} \mathrm{C}$ have been used to accumulate units in the Utah chilling model (Richardson et al., 1974), and temperatures as warm as $13{ }^{\circ} \mathrm{C}$ have been used to accumulate units in chilling models in Israel (Erez et al., 1990). As temperatures increase to $10{ }^{\circ} \mathrm{C}$, about twice as many hours are required for rest completion of peach than at $6{ }^{\circ} \mathrm{C}$ (Erez and Lavee, 1971; Erez et al., 1979). Above a specific temperature, chilling is nullified. Thus, weighted values were assigned to temperature ranges (Erez and Lavee, 1971; Richardson et al., 1974). A chilling model developed for 'Starkrimson Delicious' apple trees in North Carolina accumulated units between 1.6 and 13 ${ }^{\circ} \mathrm{C}$ (Shalout and Unrath, 1983). For highbush blueberry, a model developed in Arkansas accumulated chilling units at temperatures $<12.5^{\circ} \mathrm{C}$ (Norvell and Moore, 1982). Recently,

Received for publication 13 Jan. 2005. Accepted for publication $15 \mathrm{Feb}$. 2005. Contribution from the Missouri Agricultural Experiment Station project 322 .

${ }^{1}$ Professor.

${ }^{2}$ Graduate student. cumulated in blackberry.
Therefore, the objectives of this study were 1) to compare the time of rest completion for seven blackberry cultivars, 2) to determine the time of chilling inception, and 3) to evaluate various chilling models for estimating rest completion in erect blackberries.

\section{Materials and Methods}

Rest completion. Blackberry tissue samples of 'Apache', 'Arapaho', 'Chickasaw', 'Kiowa', 'Navaho', 'Shawnee', and 'Darrow' were obtained from a 4-year-old blackberry planting located at the Horticulture and Agroforestry Research Center, New Franklin, Mo., on 3 Dec. 2001 and 9 Jan., 5 Feb., and 7 Mar. 2002. The following season, samples were collected on 4 Dec. 2002 and 8 Jan., 5 Feb., and 4 Mar. 2003. At each sampling date, 10 eight-node sections of wood from each cultivar were removed from the middle portion of lateral canes located 60 $\mathrm{cm}$ from the soil surface. Ten single-cane replications of each cultivar were then placed in a randomized complete block design in oasis wedges (Smithers Oasis Company, Kent, Ohio) in a perlite bed in a greenhouse maintained at $21^{\circ} \mathrm{C}$. Bottom heat $\left(25^{\circ} \mathrm{C}\right)$ was supplied in the perlite bed and cuttings were misted intermittently with water $(10$ s every $10 \mathrm{~min})$ from dawn until dusk for $30 \mathrm{~d}$. Budbreak was recorded daily for a period of $30 \mathrm{~d}$ for each date of collection to determine dates of rest completion.

Chilling models. Hourly temperature data at the blackberry planting were recorded by a MetData1 weather station (Campbell Scientific, Inc., Logan, Utah). Chilling hours or units were calculated using models that varied in the time when chilling hours began accumulating (chilling inception) and in the range of temperatures that induced chilling. Because previous blackberry researchers (Drake and Clark, 2000; Yazetti and Clark, 2001) considered inception of chilling after the first killing frost $\left(-2.2^{\circ} \mathrm{C}\right)$, this method of determining chilling accumulation was included in the study for comparative purposes. The Utah chilling model (Richardson et al., 1974; Seeley, 1996) was also tested with the Julian date 240 used as the starting point

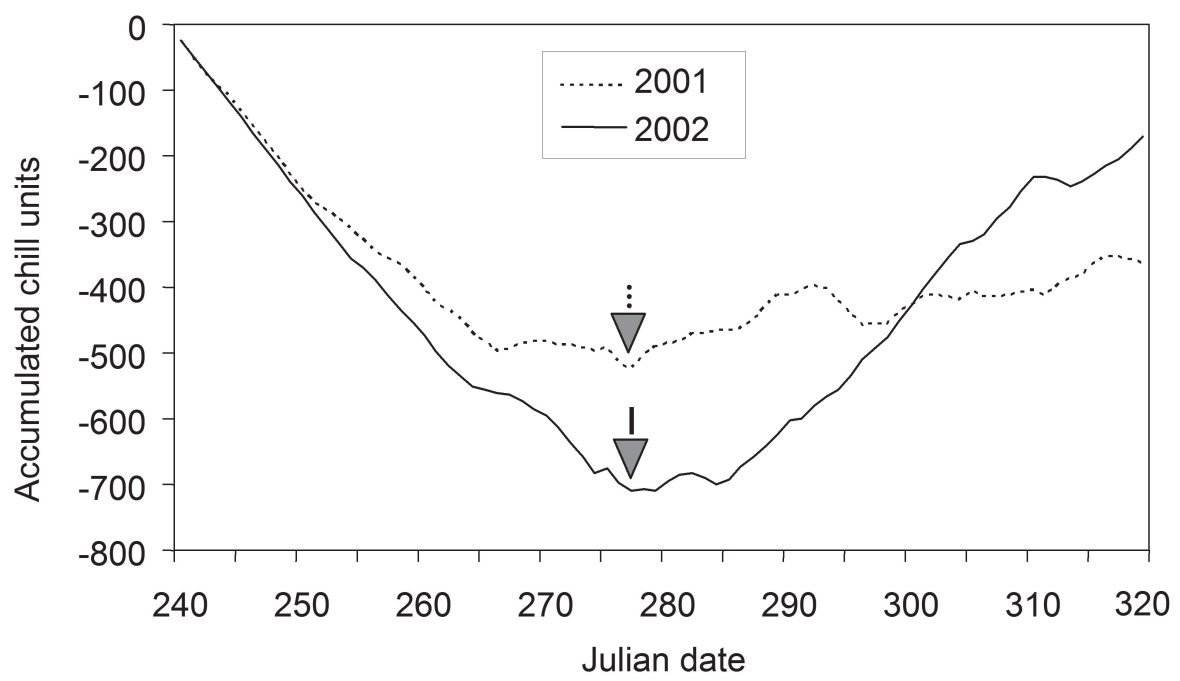

Fig. 1. The accumulation of chill units at New Franklin, Mo., calculated by the Utah peach model. Arrows indicate the maximum negative accumulation of chill units on Julian date 277 (4 Oct. 2001 and 2002). 
Table 1. Components of chilling models tested on blackberry cultivars grown at New Franklin, Mo.

\begin{tabular}{lll}
\hline Model no. & Time of chilling inception & Chill unit accumulation per hour at various temperatures $\left({ }^{\circ} \mathrm{C}\right)$ \\
\hline $1^{\mathrm{z}}$ & First incidence of $-2.2^{\circ} \mathrm{C}$ & Temperatures $<7^{\circ} \mathrm{C}=1$ chill unit \\
2 & First incidence of $-2.2^{\circ} \mathrm{C}$ & Temperatures between 0 and $7{ }^{\circ} \mathrm{C}=1$ unit \\
$3^{y}$ & The day in the fall after the maximum negative number & Weighted temperatures $\left(<1.4^{\circ} \mathrm{C}=0\right.$ unit; 1.5 to $2.4{ }^{\circ} \mathrm{C}=0.5 ; 2.5$ to $9.1{ }^{\circ} \mathrm{C}=1 ;$ \\
& of chill units (above $\left.15.9^{\circ} \mathrm{C}\right)$ was accumulated & 9.2 to $12.4{ }^{\circ} \mathrm{C}=0.5 ; 12.5$ to $15.9{ }^{\circ} \mathrm{C}=0 ; 16$ to $\left.18{ }^{\circ} \mathrm{C}=-0.5 ;>18{ }^{\circ} \mathrm{C}=-1\right)$ \\
$4^{\mathrm{x}}$ & The day in the fall when the maximum negative number & Weighted temperatures $\left(0\right.$ to $9.1^{\circ} \mathrm{C}=1 ; 9.2$ to $12.4^{\circ} \mathrm{C}=0.5 ; 12.5$ to $15.9^{\circ} \mathrm{C}=0 ;$ \\
& of chill units above $\left(15.9^{\circ} \mathrm{C}\right)$ was accumulated & 16 to $\left.18{ }^{\circ} \mathrm{C}=-0.5 ;>18{ }^{\circ} \mathrm{C}=-1\right)$ \\
$5^{\mathrm{x}}$ & First incidence of $-2.2^{\circ} \mathrm{C}$ & Weighted temperatures as in model 4 \\
\hline
\end{tabular}

${ }^{2}$ Blackberry chill model used by Yazzetti and Clark (2001).

y Utah chilling model described by Richardson et al. (1974).

${ }^{x}$ Modified Utah chilling model.

to calculate the maximum negative chill units (Fig. 1). The maximum negative accumulation of chill units (i.e., temperatures $>16^{\circ} \mathrm{C}$ ) is used to determine the inception of chilling in the Utah model (Seeley, 1996). Models evaluated in this study are presented in Table 1.

Statistical analysis. An arcsin square root transformation of the proportion of buds per cane that broke was performed and data were subjected to an analysis of variance (ANOVA) using the GLM procedure of SAS (Version 8.2; SAS Institute, 1999, Cary, N.C.). Data for the number of days to budbreak at each date of collection were also subjected to ANOVA and means were separated by Fisher's protected LSD test, $P \leq 0.05$.

\section{Results and Discussion}

Rest completion. Field temperatures at New Franklin varied between the two dormant seasons (Fig. 2). Thus, blackberry cultivars exhibited relative differences in the percent budbreak and the number of days required to break bud after exposure to warm temperatures, indicating differences in their chilling requirement. When samples were collected on 3 Dec. 2001 and placed in the greenhouse, $6 \%$ of 'Kiowa' buds grew, while none of the other cultivars exhibited growth (Table 2). Fifty-five percent of the 'Kiowa' buds and 9\% of the 'Arapaho' buds broke when collected on 4 Dec. 2002. By January sampling dates in 2002 and 2003, all cultivars except 'Darrow' had some buds that grew after warm temperature exposure in the greenhouse. All cultivars except 'Kiowa' had $<30 \%$ budbreak in Jan. 2002. In contrast, 'Apache' and 'Darrow' had fewer buds that grew than 'Kiowa', 'Arapaho', and 'Chickasaw' in Jan. 2003. By February sampling dates, 'Darrow' was the only cultivar that had $\leq 42 \%$ budbreak. Nearly $50 \%$ more 'Navaho' and 'Kiowa' buds had satisfied rest than 'Chickasaw' and 'Darrow' when sampled on 5 Feb. 2003. By March collection dates, $>80 \%$ of the buds of all cultivars exhibited growth after exposure to warm temperatures in the greenhouse.

'Kiowa' averaged $27 \mathrm{~d}$ to budbreak when collected 3 Dec. 2001 (Table 3). While two cultivars broke bud in December 2002, 'Kiowa' buds exhibited growth $19 \mathrm{~d}$ after exposure to warm temperatures. 'Arapaho' buds exhibited growth $23 \mathrm{~d}$ after sampling. In Jan. 2002, cultivars averaged 21 to $28 \mathrm{~d}$ to budbreak, except for 'Kiowa' (only $11 \mathrm{~d}$ ) and 'Darrow' (no budbreak). In January 2003, mean days to budbreak were reduced considerably, ranging from 7 to
$14 \mathrm{~d}$ for all cultivars except for 'Darrow'. By February 2003, all cultivars averaged $\leq 12$ d to budbreak, and by March, days to budbreak averaged as few as 3 to $9 \mathrm{~d}$.

Other researchers have estimated the chilling requirements for some of the Arkansas blackberry cultivars using a killing frost $(-2.2$ ${ }^{\circ} \mathrm{C}$; John Clark, personal communication) as the time of chilling inception. In an experiment using whole plants placed in cold chambers at $3{ }^{\circ} \mathrm{C}$, Drake and Clark (2000) reported that 'Arapaho' had a chilling requirement of 400 to $500 \mathrm{~h}$, while 'Navaho' plants required 800 to $900 \mathrm{~h}$. In a study using stem cuttings collected from the field, Yazzetti and Clark (2001) reported that 'Kiowa' completed rest after $200 \mathrm{~h}$ of chilling and 'Shawnee' required 400 to $500 \mathrm{~h}$ with chilling hours accumulated below $7{ }^{\circ} \mathrm{C}$. They were unable to determine conclusively the chilling requirement for 'Chickasaw', 'Apache', and 'Choctaw'. In our study, results from the December 2002 collection date showed that 'Arapaho' has a lower chilling requirement than 'Shawnee' (Table 2). Although statistical differences were not always apparent, our results indicate the following ranking of cultivars from the lowest chilling requirement to the highest: 'Kiowa'< 'Arapaho' < 'Shawnee', 'Navaho'< 'Chickasaw'<'Apache'<'Darrow'. 'Kiowa'brokebud before 'Arapaho' in Dec. 2001. The following December, 'Kiowa' and 'Arapaho' broke bud before other cultivars. 'Chickasaw' tended to have a lower percent budbreak than 'Shawnee' and 'Navaho' when collected in February, and generally required more days to budbreak than 'Shawnee'. A difference between 'Shawnee' and 'Navaho' in the length of the chilling requirement could not be elucidated based on the results of this study. Except for 'Darrow' (which did not break bud by January 2002 or 2003), 'Apache' required the most days to budbreak in January and February 2002. Thus, 'Apache' generally had a shorter chilling requirement than 'Darrow'. These results confirm those of an earlier report in which 'Apache' buds were slower to grow than 'Shawnee', 'Kiowa', and 'Arapaho' when sampled in early February (Warmund and Byers, 2002).

Chilling models. Differences between the two dormant seasons in field temperatures provided a means to compare and evaluate various chilling models. In late September and early October 2002 , temperatures $>16^{\circ} \mathrm{C}$ resulted in a greater accumulation of negative chill units than in the same period in 2001 (Fig. 1, 2). From mid-October 2002 through February 2003 , field temperatures were generally cooler than those during the same period in 2001-02 (Fig. 2). Thus, three of five models evaluated in this study accumulated a greater number of chilling units during the 2002-03 season than in the 2001-02 season (Table 4).

Model 1, which accumulated chilling hours below $0{ }^{\circ} \mathrm{C}$, resulted in the greatest number of chilling hours in 2001-02, while model 5 (modified Utah chilling model, with 0 to $9.1^{\circ} \mathrm{C}=1$ chill unit and chilling inception at

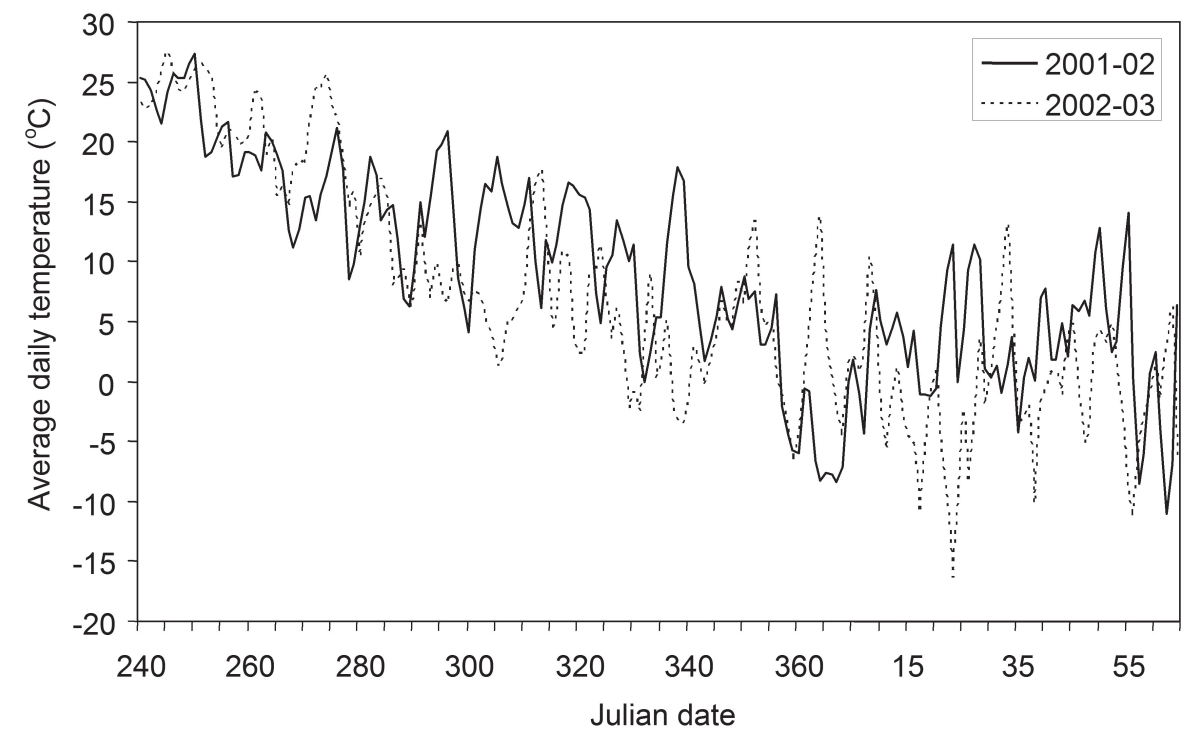

Fig. 2. Average daily temperature at New Franklin, Mo., during two dormant seasons. 
$-2.2{ }^{\circ} \mathrm{C}$ ) produced the fewest chill units by March. Model 2 accumulated few hours by 3 Dec. 2001 because chilling inception at -2.2 ${ }^{\circ} \mathrm{C}$ did not occur until 27 Oct. and the number of chilling temperatures in November was small (Table 4, Fig. 1). Model 3 (Utah chilling model) was problematic because cultivars such as 'Shawnee', 'Chickasaw', and 'Apache' broke bud by 622 chill units according to this model when sampled on 9 Jan. 2002, but did not breakbud on 4 Dec. 2002 when 724 units had accumulated. A similar problem occurred with model 4 because of the method of determining the time of chilling inception (the day after the maximum number of negative chill units accumulated above $15.9^{\circ} \mathrm{C}$ ).

Methods used to determine the inception of chilling for various crops include the first killing frost (Yazzetti and Clark, 2001), natural defoliation(Walser etal., 1981), vegetative maturity (Fuchigami etal., 1982), or the maximum negative accumulation of chilling units (Seeley, 1996). However, each of these methods was problematic when used to calculate chilling in blackberry. The temperature at which a killing frost occurs depends on the how well tissues are acclimated at the time of the cold event. A killing frost in some crops may not occur until temperatures drop to $-4.4^{\circ} \mathrm{C}$ (Decker, 1955). In our study, inception temperatures of $-3.3{ }^{\circ} \mathrm{C}$ or $-4.4^{\circ} \mathrm{C}$ did not occur until 9 Nov. or $9 \mathrm{Dec}$. 2001 , respectively, resulting in an inaccurate accumulation of chill units (data not shown). For example, with an inception temperature of $-4.4^{\circ} \mathrm{C}$, zero chilling hours or units had been accumulated by 3 Dec. 2001 but some 'Kiowa' buds grew after warm temperature exposure in the greenhouse.

Because blackberries can continue to grow into late fall (Takeda et al., 2002) and natural defoliation may not occur by late winter (Fumiomi Takeda, personal communication), defoliation is not a reliable indicator of chilling inception. Similarly, vegetative maturity, defined as the absence of regrowth after defoliation or decapitation, is problematic in determining the inception of chilling because of the lack of defoliation in some years. Moreover, regrowth can be affected by bud position on a lateral cane and by location of the lateral on the primocane in blackberry (Warmund, unpublished data), which presents sampling difficulties when determining vegetative maturity. The maximum negative number of chilling units that accumulate at temperatures above $15.9{ }^{\circ} \mathrm{C}$ is easily determined. In the present study, maximum negative accumulation occurred on 4 Oct. 2001 and 2002 (Fig. 1). As described above, the Utah model was problematic because too many chill units were calculated without budbreak in 'Shawnee', 'Chickasaw', and 'Apache' when sampled on 4 Dec. 2002.

Just as the time of chilling inception is important, the range and effectiveness of temperatures that promote chilling are also important components of a model (Erez and Lavee, 1971; Richardson et al., 1974). For rest completion, temperatures must be low enough to promote chilling, yet warm enough to promote budbreak (Naor et al., 2003). In our study, when temperatures below $0{ }^{\circ} \mathrm{C}$ were counted as one chilling hour (Table 4 , model 1), the total number of hours accumulated by the end of dormancy was large. At the December 2002 and January, February, and March 2003 sampling dates, the number of hours accumulated below $0{ }^{\circ} \mathrm{C}$ was $142,486,931$, and 1,317 , respectively (data not shown). Thus, the hours below $0{ }^{\circ} \mathrm{C}$ accounted for $57 \%$ of the hours accumulated by 4 Mar. 2003 in model 1 and temperatures as low as $-20^{\circ} \mathrm{C}$ were assigned one chilling hour. Previous work has shown that temperatures as low as $-20{ }^{\circ} \mathrm{C}$ occurring before mid-January resulted in floral bud mortality of cultivars such as 'Navaho' and 'Shawnee' (Warmund and George, 1990). Recently developed models for peach do not accumulate units below $0{ }^{\circ} \mathrm{C}$, since it was reported that temperatures below

Table 2. Percentage of blackberry buds per cutting that grew at each sampling date after exposure to $21^{\circ} \mathrm{C} .{ }^{z}$

\begin{tabular}{|c|c|c|c|c|}
\hline Cultivar & December & January & February & March \\
\hline \multicolumn{5}{|l|}{$2001-02$} \\
\hline 'Kiowa' & 6 & $95.0 \mathrm{a}^{\mathrm{z}}$ & $90.0 \mathrm{a}$ & $92.5 \mathrm{a}$ \\
\hline 'Shawnee' & 0 & $28.8 \mathrm{~b}$ & $82.5 \mathrm{ab}$ & $91.3 \mathrm{a}$ \\
\hline ‘Arapaho’' & 0 & $22.5 \mathrm{bc}$ & $87.5 \mathrm{a}$ & $97.5 \mathrm{a}$ \\
\hline 'Chickasaw' & 0 & $22.5 \mathrm{bc}$ & $60.0 \mathrm{bc}$ & $93.8 \mathrm{a}$ \\
\hline 'Apache' & 0 & $17.5 \mathrm{bc}$ & $57.5 \mathrm{c}$ & $82.5 \mathrm{a}$ \\
\hline 'Navaho' & 0 & $10.0 \mathrm{~cd}$ & $86.3 \mathrm{a}$ & $100.0 \mathrm{a}$ \\
\hline 'Darrow' & 0 & $0.0 \mathrm{~d}$ & $36.3 \mathrm{~d}$ & $85.0 \mathrm{a}$ \\
\hline \multicolumn{5}{|l|}{$2002-03$} \\
\hline 'Kiowa' & 55 & $97.5 \mathrm{a}$ & $96.3 \mathrm{a}$ & $100.0 \mathrm{a}$ \\
\hline 'Shawnee' & 0 & $40.0 \mathrm{bc}$ & $73.8 \mathrm{~b}$ & $96.3 \mathrm{abc}$ \\
\hline ‘Arapaho’' & 9 & $61.3 \mathrm{~b}$ & $88.8 \mathrm{ab}$ & $88.8 \mathrm{bcd}$ \\
\hline 'Chickasaw' & 0 & $43.8 \mathrm{~b}$ & $47.5 \mathrm{c}$ & $87.5 \mathrm{~cd}$ \\
\hline 'Apache' & 0 & $25.0 \mathrm{c}$ & $80.0 \mathrm{~b}$ & $97.5 \mathrm{ab}$ \\
\hline 'Navaho' & 0 & $41.3 \mathrm{bc}$ & $97.5 \mathrm{a}$ & $98.8 \mathrm{a}$ \\
\hline 'Darrow' & 0 & $0.0 \mathrm{~d}$ & $41.3 \mathrm{c}$ & $85.0 \mathrm{~d}$ \\
\hline
\end{tabular}

${ }^{\mathrm{z}}$ Mean separation within columns by Fisher's protected LSD test, $P \leq 0.05$.

Table 3. Average number of days to budbreak for blackberry cultivars at each sampling date after exposure to $21^{\circ} \mathrm{C}$.

\begin{tabular}{|c|c|c|c|c|}
\hline Cultivar & December & January & February & March \\
\hline \multicolumn{5}{|l|}{$2001-02$} \\
\hline 'Apache' & $--^{2}$ & $27.8 \mathrm{a}^{\mathrm{y}}$ & $14.0 \mathrm{a}$ & $8.2 \mathrm{~b}$ \\
\hline 'Chickasaw' & --- & $23.0 \mathrm{ab}$ & $11.0 \mathrm{~b}$ & $7.3 \mathrm{bc}$ \\
\hline 'Arapaho' & --- & $22.8 \mathrm{~b}$ & $7.5 \mathrm{c}$ & $5.1 \mathrm{~d}$ \\
\hline 'Navaho' & --- & $21.4 \mathrm{~b}$ & $11.0 \mathrm{~b}$ & $7.4 \mathrm{bc}$ \\
\hline 'Shawnee' & --- & $21.2 \mathrm{~b}$ & $9.3 \mathrm{bc}$ & $5.8 \mathrm{~cd}$ \\
\hline 'Kiowa' & 27 & $11.3 \mathrm{c}$ & $6.9 \mathrm{c}$ & $7.3 \mathrm{bc}$ \\
\hline 'Darrow' & --- & --- & $14.4 \mathrm{a}$ & $11.4 \mathrm{a}$ \\
\hline \multicolumn{5}{|l|}{$2002-03$} \\
\hline 'Apache' & --- & $13.2 \mathrm{ab}$ & $7.6 \mathrm{~b}$ & $3.9 \mathrm{bc}$ \\
\hline 'Chickasaw' & --- & $13.9 \mathrm{a}$ & $11.1 \mathrm{a}$ & $4.5 \mathrm{~b}$ \\
\hline 'Arapaho' & 23 & $12.0 \mathrm{abc}$ & $5.8 \mathrm{bc}$ & $4.1 \mathrm{bc}$ \\
\hline 'Navaho' & --- & $10.0 \mathrm{c}$ & $5.8 \mathrm{bc}$ & $3.6 \mathrm{bc}$ \\
\hline 'Shawnee' & --- & $11.5 \mathrm{bc}$ & $7.5 \mathrm{~b}$ & $3.4 \mathrm{bc}$ \\
\hline 'Kiowa' & 19 & $7.2 \mathrm{~d}$ & $5.0 \mathrm{c}$ & $2.9 \mathrm{c}$ \\
\hline 'Darrow' & --- & --- & $11.9 \mathrm{a}$ & $8.8 \mathrm{a}$ \\
\hline
\end{tabular}

${ }^{2}$ No budbreak observed after $30 \mathrm{~d}$ in the greenhouse.

${ }^{y}$ Mean separation within columns by years by Fisher's protected LSD test, $P \leq 0.05$.

Table 4. Chilling hours or units calculated by various models for blackberry cultivars grown at New Franklin, Mo.

\begin{tabular}{lrrrrr}
\hline Sampling & \multicolumn{5}{c}{ Models } \\
\cline { 2 - 5 } date & \multicolumn{1}{c}{1} & 2 & 3 & 4 & 5 \\
\hline 2001-02 & 215 & 191 & 326 & 332 & 260 \\
3 Dec. & 898 & 492 & 622 & 636 & 506 \\
9 Jan. & 1421 & 822 & 875 & 918 & 791 \\
5 Feb. & 1977 & 1170 & 1145 & 1177 & 1047 \\
7 Mar. & & & & 779 & 369 \\
2002-03 & 362 & 396 & 724 & 1079 & 743 \\
4 Dec. & 1070 & 759 & 808 & 1166 & 802 \\
9 Jan. & 1690 & 934 & 1061 & 1367 & 1002 \\
5 Feb. & 2310 & 1168 & 1325 & & \\
7 Mar. & & & & \\
\hline
\end{tabular}

${ }^{\mathrm{z}}$ Model 1 is the number of hours below $7^{\circ} \mathrm{C}$, with chilling inception at $-2.2^{\circ} \mathrm{C}$. Model 2 is the number of hours between 0 and $7{ }^{\circ} \mathrm{C}$, with chilling inception at $-2.2^{\circ} \mathrm{C}$. Model 3 is the Utah peach chilling model with chilling inception the day after the maximum number of negative chill units (above $15.9{ }^{\circ} \mathrm{C}$ ) was recorded in the fall. Model 4 is a modified Utah chilling method with temperatures weighted as in model 3 except for 0 to $9.1^{\circ} \mathrm{C}=1$ chill unit. Model 5 is a modified Utah chilling method with temperatures as in model 4 but chilling inception at $-2.2^{\circ} \mathrm{C}$. 
$-2{ }^{\circ} \mathrm{C}$ had no effect on breaking rest (Erez and Lavee, 1971; Erez et al., 1988, 1990). Thus, it is likely that model 1 overestimates chilling hours required for rest completion of blackberry buds. Models 3 and 4 also overestimated chilling in December 2002. Model 2 did not adequately calculate chilling. 'Arapaho' samples collected on 5 Feb. 2002 and 2003 had nearly equal budbreak (Table 2), but the number of chilling hours calculated by model 2 for these dates varied by $112 \mathrm{~h}$. In contrast, model 5 had varied by only 11 chill units in February 2002 and 2003, which was the smallest difference in the number of chilling units of all models tested. Thus, model 5 accounted for the variation among cultivars in the time of rest completion most accurately among the models tested. Additionally, this study elucidated that a blackberry model with a chilling inception temperature of $-2.2^{\circ} \mathrm{C}$ estimated chilling more accurately than the Utah chilling model, which starts chill unit accumulation immediately after the maximum negative accumulation of chill units in early fall.

\section{Literature Cited}

Chandler, W.H., M.H. Kimball, G.L. Philp, W.P. Tufts, and G.P. Weldon. 1937. Chilling requirements for opening of buds on deciduous orchard trees and some other plants in California. Calif. Agr. Expt. Sta. Bul. 611.

Childers, N.F., J.R. Morris, and G.S. Sibbett. 1995. Modern fruit science.10th ed. Horticultural Publ., Gainesville, Fla.

Dale, A., A. Sample, and E. King. 2003. Breaking dormancy in red raspberries for greenhouse production. HortScience 38:515-519.

Decker, W.L.1955. Late spring and early fall killing freezes in Missouri. Climatic atlas of Missouri no. 2. Mo. Agr. Expt. Sta. Bul. 649.

Drake, C.A. and J.R. Clark. 2000. Determination of the chilling requirement of Arkansas thornless blackberry cultivars. Student J. Dale Bumpers College Agr., Food, and Life Sci. 1:15-19.

Erez, A., G.A. Couvillon, and C.H. Hendershott. 1979. Quantitative chilling enhancement and negation in peach buds by high temperatures in a daily cycle. J. Amer. Soc. Hort. Sci. 104:573-576.

Erez, A., S. Fishman, Z. Gat, and G.A. Couvillon. 1988. Evaluation of winter climate for breaking bud rest using the dynamic model. Acta Hort. 232:76-89.

Erez, A., S. Fishman, G.C. Linsley-Noakes, and P. Allan. 1990. The dynamic model for rest completion in peach buds. Acta Hort. 276:165-173.

Erez, A. and S. Lavee. 1971. The effect of climatic conditions on dormancy development of peach buds. I. Temperature. Proc. Amer. Soc. Hort. Sci. 96:711-714.

Fear, C.D. and M.L. Meyer. 1993. Breeding and variation in Rubus germplasm for low winter chill requirement. Acta Hort. 352:295-303.

Fuchigami, L.H., C.J. Weiser, K. Kobayashi, R. Timmis, and L.V. Gusta. 1982. Adegree growth stage $\left({ }^{\circ} \mathrm{GS}\right)$ model and cold acclimation in temperate woody plants, p. 93-116. In: P.H. Li and A. Sakai (eds.). Plant cold hardiness and freezing stress mechanisms and crop implications. CRC Press, Boca Raton, Fla.

Lamb, R.C. 1948. Effect of temperatures above and below freezing on the breaking of rest in the Latham raspberry. Proc. Amer. Soc. Hort. Sci. 51:313-315.

Naor, A., M. Flaishman, R. Stern, A. Moshe, and A. Erez. 2003. Temperature effects on dormancy completion of vegetative buds in apple. J. Amer. Soc. Hort. Sci. 128:636-641.

Norvell, D.J. and J.N. Moore. 1982. An evaluation of chilling models for estimating rest requirements of highbush blueberries (Vaccinium corymbosum L.) HortScience 107:54-56.

Richardson, E.A., S.D. Seeley, and D.R. Walker. 1974. A model for estimating the completion of rest for 'Redhaven' and 'Elberta' peach trees. HortScience 9:331-332.

Seeley, S.D. 1996. Modeling climatic regulation of bud dormancy, p. 361-376. In: G.A. Lang (ed.). Plant dormancy: Physiology, biochemistry, and molecular biology. CAB Intl., Wallingford, Oxon, U.K.

Shaltout, A.D. and C.R. Unrath. 1983. Rest completion prediction model for 'Starkrimson Delicious' apples. J. Amer. Soc. Hort. Sci. 108:957-961.

Takeda, F., B.C. Strik, D. Peacock, and J.R. Clark. 2002. Cultivar differences and the effect of winter temperature on flower bud development in blackberry. J. Amer. Soc. Hort Sci. 127:495-501.

Walser, R.D., D.R. Walker, and S.D. Seeley. 1981. Effect of temperature, fall defoliation, and gibberellic acid on the rest period of peach leafbuds. J. Amer. Soc. Hort. Sci. 106:91-94.

Warmund, M.R. and P.L. Byers. 2002. Rest completion in seven blackberry (Rubus sp.) cultivars. Acta Hort. 585:693-696.

Warmund, M.R. and M.F. George. 1990. Freezing survival and supercooling in primary and secondary buds of Rubus spp. Can. J. Plant Sci. 70:893-904.

Weinberger, J.H. 1950. Chilling requirements of peach varieties. Proc. Amer. Soc. Hort. Sci. 56:123-133.

Westwood, M.N. 1993. Temperate-zone pomology physiology and culture, p. 386. Timber Press, Portland, Ore.

Yazzetti, D. and J.R. Clark. 2001. Evaluation of chilling requirements for six Arkansas blackberry cultivars utilizing stem cuttings. Student J. Dale Bumpers College Agr., Food, and Life Sci. 2:90-94. 